\title{
Surface water quality and deforestation of the Purus river basin, Brazilian Amazon
}

\author{
Eduardo Antonio Ríos-Villamizar (1) • Maria T. F. Piedade • \\ Wolfgang J. Junk • Andréa Viviana Waichman
}

Received: 7 October 2016/Accepted: 21 November 2016/Published online: 2 December 2016

(C) The Author(s) 2016. This article is published with open access at Springerlink.com

\begin{abstract}
In the last years, deforestation constitutes a threat for the aquatic ecosystems. This paper aims to characterize the water quality of the Purus river in the Brazilian Amazon, and investigate the relations between water quality and deforestation of the Purus river basin over a 9-year period, as well as to quantify the Purus river basin's land cover changes $(\%)$ in a 5-year period. Sampling data from upstream to downstream show a decrease in $\mathrm{pH}$-value, dissolved oxygen, electrical conductivity, and total suspended solids. Correlation analysis revealed a significant negative correlation of the accumulated total deforestation values $\left(\mathrm{km}^{2}\right)$ with the $\mathrm{pH}$-value (in all the study sites), and a significant positive correlation with temperature (only in two sites). However, the deforestation rates $\left(\mathrm{km}^{2} /\right.$ year) did not present, in none of the study stations, any significant correlation with water quality parameters. It seems that the effects of deforestation on water quality are related not with the rate but with the total area deforested. It was estimated that the basin's forested area decreased by $5.17 \%$. Since similar attributes are common in other basins of the whitewater systems of the Brazilian Amazon, this results may be seen as a warning on the effects of deforestation on water quality (reduction in $\mathrm{pH}$ and increment in temperature values), in larger areas than those of our study sites. To maintain the conservation and preservation status of the Purus river basin, it is necessary, the implementation of a transboundary watershed management program that could serve as a conservation model for Brazil and other countries of the Amazonian region.
\end{abstract}

Keywords Amazon basin · Deforestation · Purus · Water quality

\section{Introduction}

The Amazon, that presents different characteristics among others Brazilian hydrographic areas, is one of the world's unique regions containing most of the usable water resources in Brazil. This water potential displays

E. A. Ríos-Villamizar $(\bowtie) \cdot$ M. T. F. Piedade

Instituto Nacional de Pesquisas da Amazônia/Ecologia, Monitoramento e Uso Sustentável de Áreas Úmidas Amazônicas (Grupo MAUA/CDAM/INPA), Campus I, Av. André Araújo, 2.936, Petrópolis, Caixa Postal 478, CEP: 69067-375 Manaus,

Brazil

e-mail: eduardorios17@hotmail.com

W. J. Junk

Instituto Nacional de Ciência e Tecnologia em Áreas Úmidas (INCT-INAU-UFMT), Cuiabá, Brazil

A. V. Waichman

Universidade Federal do Amazonas - UFAM/ICB, Manaus, Brazil 
privileged place into the speeches on Amazonian sustainable development. Water chemistry provides important parameters for quantifying biogeochemical cycles and determines management options in river systems and wetlands. The first scientific classification of Amazonian rivers was elaborated by Sioli (1956) who used water color, transparency, $\mathrm{pH}$ and electrical conductivity to explain limnological characteristics of the large Amazonian rivers and correlated these characteristics to the geological properties of the river catchments, a landscape ecology approach. Whitewater rivers (such as the Amazon, Juruá and Madeira) are turbid and have their origins in the Andes, from which they transport large amounts of nutrient-rich sediments. Their waters have near neutral $\mathrm{pH}$ and relatively high concentrations of dissolved solids indicated by the electric conductivity that varies between 40 and $140 \mu \mathrm{S} \mathrm{cm}^{-1}$. Blackwater rivers (such as the Negro River) drain the Precambrian Guiana shield, which is characterized by large areas of white sands (podzols), their waters show low quantities of suspended matter but high amounts of humic acids that give the water a brownish-reddish color. The $\mathrm{pH}$ values of such rivers are in the range of 4-5 and their electrical conductivity is $<20 \mu \mathrm{S} \mathrm{cm}^{-1}$. Clearwater rivers (such as the Tapajós and Xingu rivers) have their upper catchments in the Cerrado region of the Central Brazilian archaic shield. The transparency of their greenish waters is above $1.5 \mathrm{~m}$, with low amounts of sediments and dissolved solids, electrical conductivity is in the range of $10-20 \mu \mathrm{S} \mathrm{cm}^{-1}$, and $\mathrm{pH}$ that varies between 6 and 7 in large rivers.

Ríos-Villamizar et al. (2014) classified a number of rivers using the combination of several parameters such as alkali $(\mathrm{Na}, \mathrm{K})$ and alkali-earth $(\mathrm{Ca}, \mathrm{Mg})$ metals, major anions, electrical conductivity, $\mathrm{pH}, \mathrm{N}_{\text {total }}, \mathrm{P}_{\text {total }}$, water color and suspended sediment load to distinguish the three classical water types (white, black and clear) and to separate other water bodies with intermediate position, concluding that many rivers and streams have to be considered as mixed waters resulting from the influence of lower order tributaries with different physicochemical properties of their waters. According to this classification system, the Purus river is a whitewater river but many of its tributaries are of intermediate type (Ríos-Villamizar et al. in preparation) if considering that the geology of the pre-Andean zone is rather heterogeneous with large old sedimentation areas (paleovarzeas), which sediments are strongly weathered, but still have a higher bioelement content than the tertiary sediments of the central Amazon basin and the soils on the archaic shields.

The Purus river is one of the chief tributaries of the Solimões/Amazon River system, being one of the longest rivers in South America, rising in the eastern lowlands of Peru and flowing about 3380 kilometres (km) before entering Solimões river at the northwestern Brazil. The estimated water volume that is generated within the Purus river basin is about $8500 \mathrm{~m}^{3} \mathrm{~s}^{-1}$, and the total area of this basin is about $375,458 \mathrm{~km}^{2}$. The Purus basin is classified into the basin group that still is in a high conservation status in the Brazilian Amazon (Fig. 1). However, in recent years, the cattle ranching, the advance of the agricultural frontier mainly for soybean production and the associated deforestation constitute a threat for the aquatic ecosystems.

\section{Materials and methods}

The aims of this paper are to diagnose water quality changes at the main channel of the Purus river, and to relate these with deforestation rates $\left(\mathrm{km}^{2} /\right.$ year) and accumulated total deforestation values $\left(\mathrm{km}^{2}\right)$ of the Purus

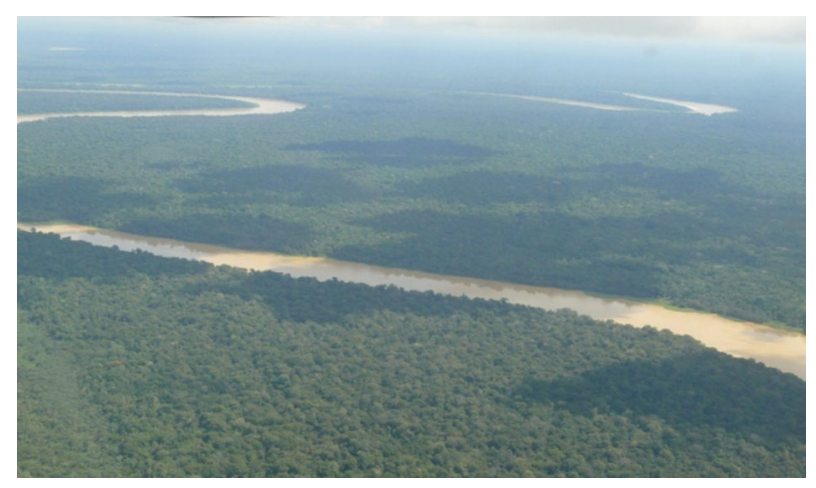

Fig. 1 A section of the middle/lower Purus river basin 


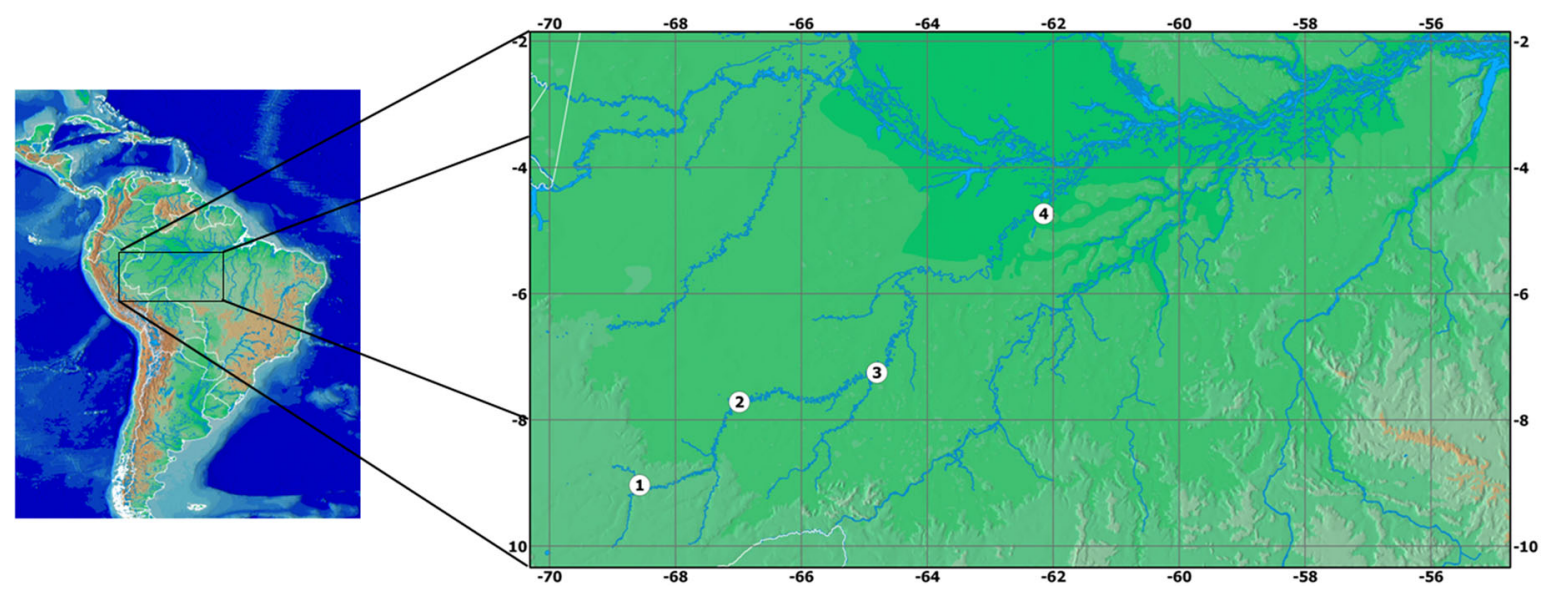

Fig. 2 Location of the ANA's water quality monitoring stations on the Purus river: 1 Seringal Caridade (Municipal District of Boca do Acre); 2 Seringal Fortaleza (Municipal District of Pauini); 3 Lábrea (Municipal District of Lábrea); 4 Arumã (Municipal District of Beruri). Classes: green color forest; blue color hydrography

basin, over a 9-year period, to detect spatial and temporal relationships, using Spearman's rank and Pearson correlation analysis, which were performed using Open Stat 4.0. The time series of data were constituted by the results of, at least, three samplings per year in each monitoring station. The information on deforestation (PRODES 2007) was reported by the Brazilian National Institute of Spatial Research (INPE), and the data regarding to water quality were recorded by the Brazilian National Agency of Water (ANA) (HIDROWEB 2007), see Fig. 2. Water samples were collected in the center of the river channel using acid-washed polyethylene bottles, which were rinsed with the water being collected and the samples were manually collected beneath the surface and kept cool until the time of analysis. Water samples were filtered through Whatman GF/F fiberglass filters $(0.45 \mu \mathrm{m})$. The values of electrical conductivity $\left(\mu \mathrm{S} \mathrm{cm}^{-1}\right.$ at $\left.25{ }^{\circ} \mathrm{C}\right)$, dissolved oxygen $\left(\mathrm{mg} \mathrm{O}_{2} \mathrm{l}^{-1}\right)$, temperature $\left({ }^{\circ} \mathrm{C}\right)$ and $\mathrm{pH}$ were measured in the field (on site). In the laboratory, the values of turbidity (NTU) and total suspended solids $\left(\mathrm{mg} \mathrm{l}^{-1}\right)$ were analyzed. All the analyses were carried out by standard methods (APHA 2005). The Purus river basin's land cover changes (\%), in a 5-year period, also were identified (diagnosed) by comparing two maps which used remote sensing and geographical information systems (GIS) techniques.

\section{Results and discussion}

Water quality trends

The waters of the Purus river basin showed characteristics of Amazonian natural waters (Furch and Junk 1997). The electrical conductivity and the total suspended solids decrease from upstream to downstream of the Purus river, probably explained because of the increase of activities associated with the use of land, such as deforestation, cattle breeding and agriculture, concentrated in the municipalities of Boca do Acre and Lábrea, which are located in the Amazonas State in Brazil. It could be related with four deforestation fronts, corresponding with migratory processes, proceeding from the neighboring Brazilian States (Acre and Rondônia), which are stimulated by the agriculture expansion and wood predatory exploration (Sanches et al. 2007). Nevertheless, it was observed an increase in turbidity from upstream to downstream that would be explained by the soil loss and sediments transport from all the contribution areas along the basin (Leonardo 2003). This phenomenon also could be responsible for the slight decrease in dissolved oxygen in the same direction. Since it would be expected a general decreasing trend for total suspended solids and turbidity, the observed opposite trend for these two parameters, as well as the increasing trend for turbidity could be explained by possible measurement inaccuracies of the turbidity meter used. The $\mathrm{pH}$-value decreased from upstream to downstream and the temperature shows a slight increase in the same direction (Fig. 3). This last trend could be due to the entrance of acidic blackwater tributaries which may contribute to $\mathrm{pH}$ and temperature changes. 

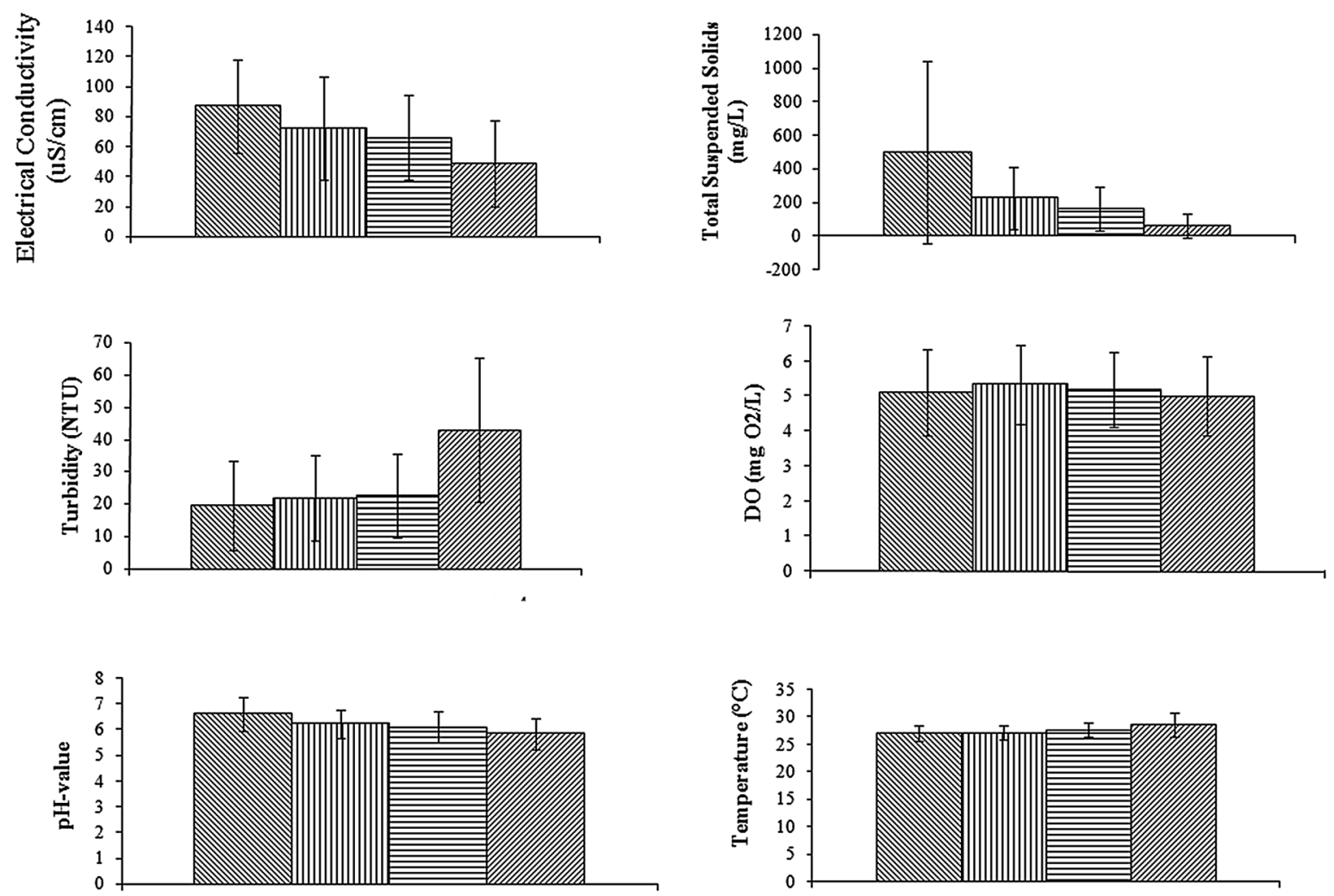

\section{\$Station 1 mStation 2 घStation 3 øStation 4}

Fig. 3 Average values and standard deviation (SD) of the water quality variables for each monitoring station of the ANA in the Purus river (1998-2006)

Relations of the water quality with deforestation variables

Table 1 presents the accumulated total deforestation data for the years 2000-2006 and the deforestation rates for the years 2001-2006, respectively.

The higher deforestation rates were observed in Boca do Acre and Lábrea, with larger total deforested areas probably related with the access by road to the floodplain areas. The lower rates were observed in Pauini and Beruri (Arumã) where the access to the floodplain forest by road is almost inexistent. No relation was found among deforestation rates and the water quality parameters at the four sites. On the other hand, ATD showed

Table 1 Deforestation levels for the municipal districts of the study (PRODES 2007)

\begin{tabular}{|c|c|c|c|c|c|c|c|c|}
\hline \multirow[t]{2}{*}{ Year } & \multicolumn{2}{|c|}{ Boca do Acre } & \multicolumn{2}{|l|}{ Pauini } & \multicolumn{2}{|l|}{ Lábrea } & \multicolumn{2}{|l|}{ Beruri } \\
\hline & ATD & DR & ATD & DR & ATD & DR & ATD & DR \\
\hline 2000 & 1165.9 & - & 146.8 & - & 1245.1 & - & 181.4 & - \\
\hline 2001 & 1216.2 & 50.3 & 154.7 & 7.9 & 1419.8 & 174.7 & 189.2 & 7.8 \\
\hline 2002 & 1319.8 & 103.6 & 164.8 & 10.1 & 1625.9 & 206.1 & 191.7 & 2.5 \\
\hline 2003 & 1570.6 & 250.8 & 177.5 & 12.7 & 2083.5 & 457.6 & 197.2 & 5.5 \\
\hline 2004 & 1693.7 & 123.1 & 184.5 & 7.0 & 2449.5 & 366.0 & 200.2 & 3.0 \\
\hline 2005 & 1747.3 & 53.6 & 193.5 & 9.0 & 2631.3 & 181.8 & 200.9 & 0.7 \\
\hline 2006 & 1831.9 & 84.6 & 201.1 & 7.6 & 2910.5 & 279.2 & 203.3 & 2.4 \\
\hline
\end{tabular}

- Not reported

$A T D$ accumulated total deforestation $\left(\mathrm{km}^{2}\right), D R$ deforestation rate $\left(\mathrm{km}^{2} /\right.$ year $)$ 
Table 2 Correlation coefficient analysis among DR, ATD and water quality variables in the Purus river basin (2000-2006)

\begin{tabular}{|c|c|c|c|c|c|c|c|c|}
\hline & ATD 1 & DR 1 & ATD 2 & DR 2 & ATD 3 & DR 3 & ATD 4 & DR 4 \\
\hline Temp1 & $0.403 * *$ & $0.216 * *$ & & & & & & \\
\hline pH 1 & $-0.883^{*}$ & $0.132 * *$ & & & & & & \\
\hline E.C 1 & $-0.584 * *$ & $-0.326^{* *}$ & & & & & & \\
\hline Turb 1 & $-0.417 * *$ & $-0.042 * *$ & & & & & & \\
\hline D.O 1 & $0.441 * *$ & $0.356^{* *}$ & & & & & & \\
\hline TSS 1 & $-0.011 * *$ & $-0.364 * *$ & & & & & & \\
\hline Temp 2 & & & $0.863^{*}$ & $0.035 * *$ & & & & \\
\hline pH 2 & & & $-0.765^{*}$ & $-0.382 * *$ & & & & \\
\hline E.C 2 & & & $-0.107 * *$ & $-0.543 * *$ & & & & \\
\hline Turb 2 & & & $-0.631 * *$ & $0.071 * *$ & & & & \\
\hline D.O 2 & & & $0.671 * *$ & $-0.219 * *$ & & & & \\
\hline TSS 2 & & & $0.572 * *$ & $0.322 * *$ & & & & \\
\hline Temp 3 & & & & & $0.793 *$ & $0.174 * *$ & & \\
\hline $\mathrm{pH} 3$ & & & & & $-0.971 *$ & $-0.430 * *$ & & \\
\hline E.C 3 & & & & & $-0.433 * *$ & $-0.558 * *$ & & \\
\hline Turb 3 & & & & & $-0.760 *$ & $-0.124 * *$ & & \\
\hline D.O 3 & & & & & $0.941^{*}$ & $0.388 * *$ & & \\
\hline TSS 3 & & & & & $-0.159 * *$ & $0.193 * *$ & & \\
\hline Temp 4 & & & & & & & $0.511 * *$ & $-0.455 * *$ \\
\hline $\mathrm{pH} 4$ & & & & & & & $-0.828 *$ & $0.598 * *$ \\
\hline E.C 4 & & & & & & & $-0.284 * *$ & $0.680 * *$ \\
\hline Turb 4 & & & & & & & $0.154 * *$ & $0.399 * *$ \\
\hline D.O 4 & & & & & & & $-0.259 * *$ & $0.305 * *$ \\
\hline TSS 4 & & & & & & & $0.848^{*}$ & $-0.506 * *$ \\
\hline
\end{tabular}

1 Station 1, 2 Station 2; 3 Station 3, 4 Station 4, Temp temperature $\left({ }^{\circ} \mathrm{C}\right)$, E.C electrical conductivity $\left(\mu \mathrm{S} \mathrm{cm}{ }^{-1}\right)$, Turb turbidity (NTU), D.O dissolved oxygen $\left(\mathrm{mg}^{-1} \mathrm{O}_{2}\right)$, TSS total suspended solids $\left(\mathrm{mg} \mathrm{l}^{-1}\right), A T D$ accumulated total deforestation $\left(\mathrm{km}^{2}\right), D R$ deforestation rate $\left(\mathrm{km}^{2}\right.$ year $\left.{ }^{-1}\right)$

* Significant $(P<0.05)$; ** non-significant $(P>0.05)$

relationships with water quality mainly in station 3 (Lábrea) where larger ATD values were observed. The ATD values correlates with changes in temperature in stations 2 and 3, with total suspended solids in station 4, with dissolved oxygen in station 3, with $\mathrm{pH}$-value in all the four stations, and with turbidity in station 3 (Table 2). It is remarkable, the significant negative relationship between the ATD and pH-value, indicating that increase in the ATD will contribute to decrease the water $\mathrm{pH}$-value. Comparable pattern was already obtained in other basins in USA, Brazil, Indonesia and India (Kunkle 1974; Neal et al. 1992; Arceivala and Asolekar 2006; Hirano et al. 2007). Deforestation likely contributes to increase the concentration of nitrates (nitrification) in the river water, and the increased hydrogen ions, released through increased nitrification, cause the water pH-value decrease (Lampert and Sommer 1997; Arceivala and Asolekar 2006). Since deforestation often causes the loss of soil carbon and a net release of $\mathrm{CO}_{2}$, the increasing deforestation processes in some parts of the basin may also contribute to the intensification of carbon $\left(\mathrm{CO}_{2}\right)$ release from soils, with associated changes in content and composition of this gas on river water, which may result in alterations on water pH-value (Mizuno and Mori 1970; Wissmar et al. 1981; Goudie 2000; Soulsby et al. 2002; Hirano et al. 2007; Iyobe and Haraguchi 2008; Lal et al. 2015).

Land use changes

In the Purus river basin, as a whole, the highest percentage of the area is represented by forested land since it covered $85.8 \%$ of the total area in 2007. However, this basin suffered a relative intense process of land use and changes on the cover composition in the period 2003-2007. Forests were cleared to give way to expansion of 


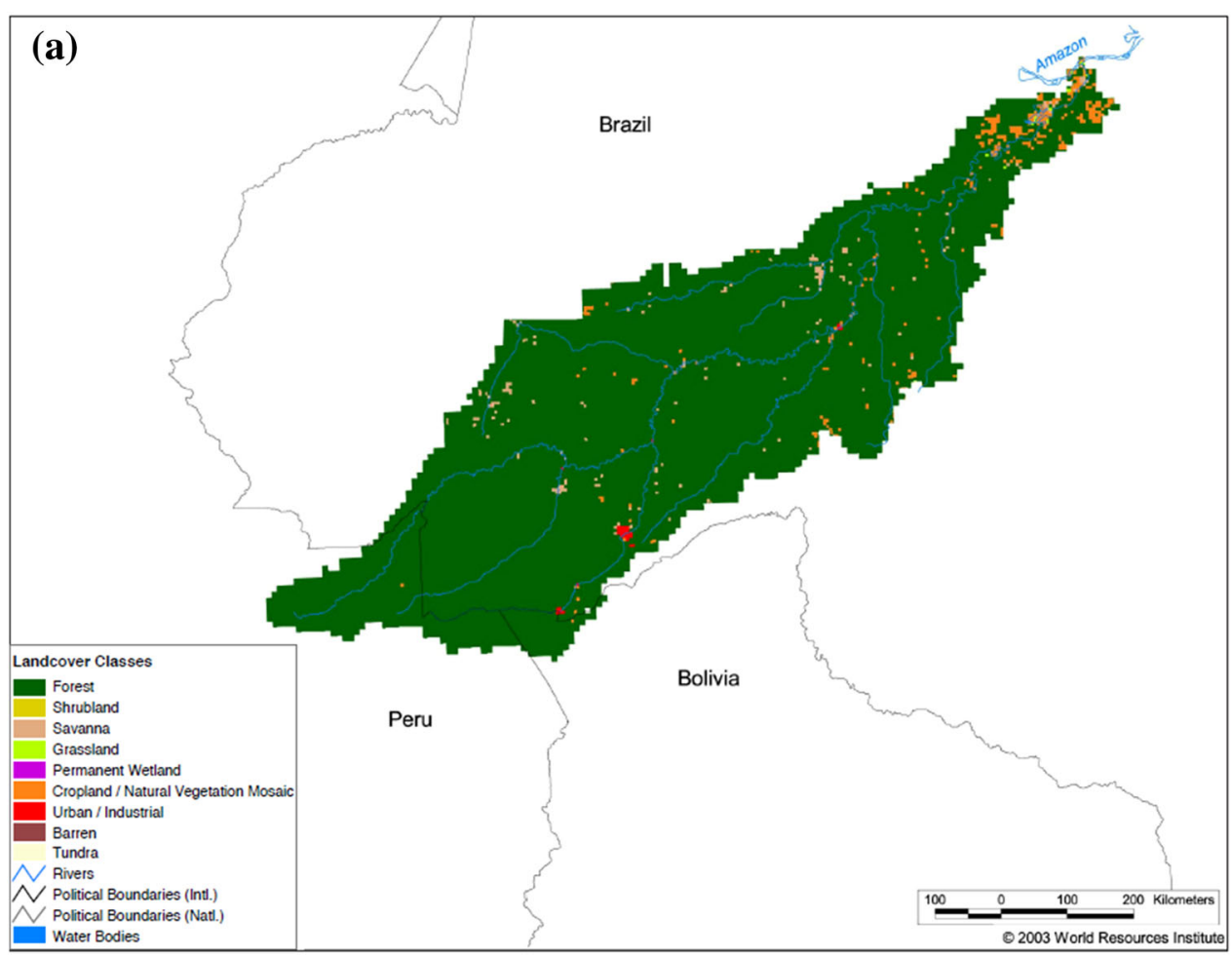

(b) Urban
area $\begin{aligned} & \text { Water } \\ & \text { bodies }\end{aligned}$ Forest $\begin{aligned} & \text { Secondary } \\ & \text { forest }\end{aligned} \quad \begin{aligned} & \text { Deforested } \\ & \text { area }\end{aligned}$ Other $\begin{aligned} & \text { Aquatic } \\ & \text { macrophytes }\end{aligned}$

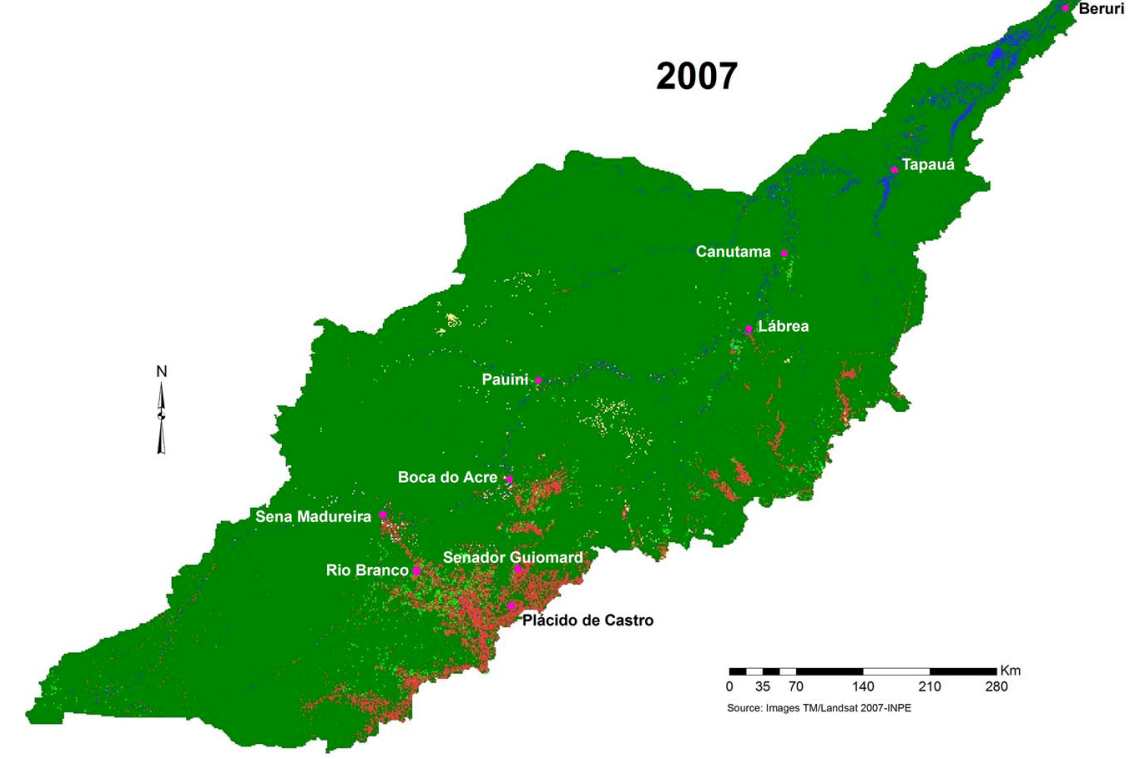

Fig. 4 Comparison of land cover and use maps in the Purus river basin. a 2003 (Water Resources eAtlas 2003); b 2007 (modified from Ríos-Villamizar et al. 2011)

cattle ranching and farming lands on this basin. According to the spatial sequence displayed by the INPE data, the deforestation rates are further increasing at the municipal districts located at south and southeast of the Amazon region. In this sense, the larger deforested areas along the basin are concentrated close to urban areas of the municipal districts of Rio Branco, Sena Madureira, Plácido de Castro and Senador Guiomard, in the 
Table 3 Land cover variables percents in the Purus river basin on 2003 and 2007

\begin{tabular}{llr}
\hline Land cover variables & $2003(\%)^{\mathrm{a}}$ & $2007(\%)^{\mathrm{b}}$ \\
\hline Urban area & 0.1 & 0.13 \\
Deforested area & $6.7^{\mathrm{c}}$ & 5.48 \\
Forest cover & 91.0 & 85.83 \\
Hydrography & - & 1.6 \\
Wetlands (Várzea) & 7.0 & 5.9 \\
Aquatic macrophytes & - & 0.01 \\
Secondary forest & - & 0.89 \\
Other & $\mathrm{d}$ & $0.23^{\mathrm{e}}$ \\
\hline
\end{tabular}

- Not reported

a Water Resources eAtlas (2003) (Basin area: 371,042.0 km²)

${ }^{\mathrm{b}}$ Ríos-Villamizar et al. (2011) (Basin area: $375,458.5 \mathrm{~km}^{2}$ )

c Percent loss of original forest cover

d This category includes percent grassland, savanna and shrubland (3.9\%), and percent cropland (3.9\%)

e This category includes cloudy area

Acre State; and Lábrea and Boca do Acre, in the Amazonas State (Fig. 4b). It is evident that the reduction of forest cover was roughly 5.17\% in the period 2003-2007 (Fig. 4; Table 3). Another important aspect of the identified changes is that wetlands area lost approximately $1.1 \%$ in the same period, but this variation would also be due to the effects of the flood pulse, during natural seasonal periods, on the rivers and lakes' water level (Junk et al. 1989; Junk and Wantzen 2004).

\section{Conclusions}

The analyzed waters of the Purus river basin showed typical characteristics of Amazonian natural waters. We observed clear trends in changes of physico-chemical properties of water from upstream to downstream of the Purus river such as decrease in $\mathrm{pH}$-value, dissolved oxygen, electrical conductivity, total suspended solids, and increase in turbidity. Only the $\mathrm{pH}$-value presented significant negative relationships with the ATD in all the study sites, indicating that increase in the ATD will contribute to decrease the water $\mathrm{pH}$-value. On the other hand, the ATD values correlated positively and significantly with changes of temperature only in stations 2 and 3, indicating that increase in the ATD will contribute to increase the water temperature. The DR did not present, in none of the study stations, any significant relation with the water quality parameters. Then, the deforestation levels have not yet caused a large effect on the water quality, which is probably most influenced by hydrological and climatic factors such as river discharge, river level, and pluvial precipitations, among others; but this will be addressed in forthcoming papers.

It seems that the effects of deforestation on water quality are related not with the rate but with the total area deforested, and they become apparent after a minimal size of deforested area is achieved.

Therefore, despite the good conservation status for most parts of the Purus river basin, impacts on water quality caused by human activities are evident, especially close to urban areas, at a local scale. Since similar attributes are common in other basins of the whitewater systems of the Brazilian Amazon, this may be seen as a warning on the effects of deforestation on water quality in larger areas than those of our study sites. Actions to control the deforestation in this basin would need to be taken to maintain its conservation status and, in view of that, it would be necessary to implement a transboundary watershed management program for conservation and preservation purposes, and this program could serve as a conservation model for Brazil and other Amazonian countries.

Acknowledgements This work was funded by Brazilian National Scientific Council (CNPq), Tropical Forest Protection Program (PPG-7), Grant Number 556899/2005-9. We thank the postgraduate Program of Environmental Sciences and Sustainability in the Amazon (PPG/CASA/UFAM), the postgraduate Program in Climate and Environment at the National Institute of Amazonian Research (INPA/UEA), the Ecology, Monitoring and Sustainable Use of Wetlands Group (MAUA/CDAM/INPA), CAPES/ 
CNPq_IEL Nacional—Brasil, Programa de Apoio à Fixação de Doutores no Amazonas (FIXAM/AM) and Programa de Apoio à Participação em Eventos Científicos e Tecnológicos (PAPE), from the Fundação de Amparo à Pesquisa do Estado do Amazonas (FAPEAM/SECTI/AM) for financial support. We also thank Kyara Martins Formiga by suggestions and elaboration of the study area map.

Open Access This article is distributed under the terms of the Creative Commons Attribution 4.0 International License (http:// creativecommons.org/licenses/by/4.0/), which permits unrestricted use, distribution, and reproduction in any medium, provided you give appropriate credit to the original author(s) and the source, provide a link to the Creative Commons license, and indicate if changes were made.

\section{References}

APHA, AWWA and WEF (2005) Standard methods for the examination of water and wastewater, 21st ed. American Public Health Association, Washington, D.C

Arceivala SJ, Asolekar SR (2006) Wastewater treatment for pollution control and reuse. Tata McGraw-Hill Education. New Delhi. https://books.google.com.br/books?isbn=0070620997. Accessed 17 Nov 2016

Furch K, Junk WJ (1997) Physicochemical conditions in the floodplains. In: Junk WJ (ed) The central Amazon floodplain: ecology of a pulsing system. Springer-Verlag, Berlin, pp 69-108

Goudie A (2000) The human impact on the natural environment. MIT Press, Cambridge

HIDROWEB (2007) Hydrologic information system of the ANA. http://hidroweb.ana.gov.br/. Accessed 20 Jun 2007

Hirano T, Segah H, Harada T et al (2007) Carbon dioxide balance of a tropical peat swamp forest in Kalimantan, Indonesia. Glob Change Biol 13:412-425

Iyobe T, Haraguchi A (2008) Ion flux from precipitation to peat soil in spruce forest-Sphagnum bog communities in the Ochiishi district, eastern Hokkaido, Japan. Limnology 9:89-99

Junk WJ, Wantzen KM (2004) The flood pulse concept: new aspects, approaches, and applications—an update. In: Proceedings of the 2nd international symposium on the management of large rivers for fisheries, Bangkok, Thailand, vol 2, pp 117-149

Junk WJ, Bayley PB, Sparks RE (1989) The flood pulse concept in river-floodplain-systems. Can Special Publ Fish Aquat Sci 106:110-127

Kunkle SH (1974) Water-its quality often depends the forester. Technical document Unasylva 105 FAO. http://www.fao.org/ docrep/e7730e/e7730e02.html. Accessed 27 Apr 2008

Lal R, Singh BR, Mwaseba DL, Kraybill D, Hansen D O, Eik LO (2015) Sustainable intensification to advance food security and enhance climate resilience in Africa. Springer. Switzerland. https://books.google.com.br/books?isbn=9783319093604. Accessed 18 Nov 2016

Lampert W, Sommer U (1997) Limnoecology: the ecology of lakes and streams. Oxford University Press, New York

Leonardo HCL (2003) Soil and water quality indicators to evaluate the sustainable use of the rio Passo Cue watershed in western Paraná. Master Dissertation, University of São Paulo, Brazil

Mizuno T, Mori S (1970) Preliminary hydrobiological survey of some southeast asian inland waters. Biol J Linn Soc 2:77-117

Neal C, Forti MC, Jenkins A (1992) Towards modelling the impact of climate change and deforestation on stream water quality in Amazonia: a perspective based on the MAGIC model. Sci Total Environ 127:225-241

PRODES (2007) Via satellite Brazilian Amazonian forest monitoring project-INPE deforestation database. http://www.dpi.inpe. br/prodesdigital/prodesmunicipal.php. Accessed 25 Apr 2007

Ríos-Villamizar EA, Junior AFM, Waichman AV (2011) Water physico-chemical characterization and soil use in the Purus river basin, western Brazilian Amazon. Rev Geogr Acadêmica 5(2):54-65

Ríos-Villamizar EA, Piedade MTF, Costa JG et al (2014) Chemistry of different Amazonian water types for river classification: a preliminary review. WIT Trans Ecol Environ 178:17-28

Sanches MV, Assis FP, Bueno CR et al (2007) Environmental and sustainability analysis of the Amazonas State. United Nations Publication, Santiago

Sioli H (1956) Über Natur und Mensch im brasilianischen Amazonasgebiet. Erdkunde 10(2):89-109

Soulsby C, Gibbins C, Wade AJ et al (2002) Water quality in the Scottish uplands: a hydrological perspective on catchment hydrochemistry. Sci Total Environ 294:73-94

Water Resources eAtlas (2003) Watersheds of south America (SA01 Amazon, Purus). The world conservation union (IUCN), IWMI, RAMSAR, WRI, pp 1-2

Wissmar RC, Richey JE, Stallard RF et al (1981) Plankton metabolism and carbon processes in the Amazon river, its tributaries and floodplain waters, Peru-Brazil, May-June 1977. Ecology 62:1622-1633 